\title{
Intravital method for the obtaining genital products from the male african catfish
}

\author{
Irina Tkacheva ${ }^{1,1}$, Anton Kuzov ${ }^{2}$, Sergey Polienko ${ }^{3}$, and Vyacheslav Polyakov ${ }^{4}$ \\ ${ }^{1}$ Don State Technical University, 344003, Gagarina 1, Rostov-on-Don, Russia \\ ${ }^{2}$ Federal Research Centre The Southern Scientific Centre of the Russian Academy of Sciences (SSC \\ RAS), 344006, Chekhov ave., 41, Rostov-on-Don, Russia \\ ${ }^{3}$ Azerbaijan Fish Farm MMC, Neftchiler ave, Port Baku Towers, 160004, Baku, Azerbaijan \\ ${ }^{4}$ Aquaproduct, Zosimovskay, 107, Vologda, Russia
}

\begin{abstract}
In industrial aquaculture, spawning of $t^{*}$ he Clarias catfish (lat. Clarias gariepinus) is complicated by the fact that it is impossible to obtain sperm due to the physiology of the fish. Fish farmers deal with the problem in different ways. They have to expect natural spawning, do a resection of the gonads or kill and dissect the fish (slaughter). We would like to propose a method for collecting sperm through the puncture of the gonads of the fish. The method is intended to save male broodstock. If the weight of the fish does not exceed $2 \mathrm{~kg}$, the procedure can be performed any anesthesia. There is no need for the fish to be separated from the rest of the broodstock after the surgery. 43 of the 65 stimulated one-year-old males with an average weight of $1250 \mathrm{~g}$ have given motile sperm with a volume of $1.5 \pm 0.1 \mathrm{ml}$.
\end{abstract}

\section{Introduction}

Spawning work in breeding of the African catfish in industrial aquaculture is complicated by the male vas deferens structures [1]. It is impossible to obtain seminal fluid by decantation using modern methods of physiological and / or environmental stimulation of reproduction.

In modern aquaculture there are 3 widespread methods for the reproduction of the African catfish with various approaches to obtaining genital products:

- spawning of the fish can be carried out in the imitation of the natural conditions [1];

- sperm extraction can be effected by the fish killing and extraction of the gonads [2],

- sperm extraction is based on an invasive procedure - resection (ectomy) of the part of the gonads that requires stitches [3].

\section{Ecological method}

A fish farmer forms a family of several females and males [4], which is kept in the environment conductive to maturation - feeding [5-6], temperature [7-9], hydrochemistry

${ }^{*}$ Corresponding author: tkacheva-irina85@mail.ru 
[10-11] and photoperiod [7, 12]. During spawning company, the family is placed in a prepared pond or fish tank with a substrate for laying eggs [13]. After spawning, the family is removed from the pond until the prelarvae hatch, or the substrate with the eggs is transferred to incubation tanks.

\section{Physiological method with killing of males}

Most fish farms use this technique if they practice the artificial breeding of African catfish. The broodstock is also kept under ideal conditions for maturation [10]. Before the spawning process, fish have being kept for 2 days in separate tanks without feeding. After injecting the male broodfish with the medicine that stimulate the maturation of gonads [14-16], before the eggs are taken away from the mature females, the male is killed, his abdominal cavity is opened and a part or all of the gonad with developed milt is extracted (Figure 1). Next, the gonad is cut or forced through a sieve in order to obtain seminal fluid, which is then diluted with water and mixed with the eggs for fertilization.

It takes about 3 minutes to remove the genital products from 1 male through killing and autopsy of the fish. In this case, the male is used once, which excludes the possibility of selection in the broodstock.

It must be considered that males can produce low-quality sperm and you should always have several spare males for the spawning - as a rule, 3 males for 1 female.

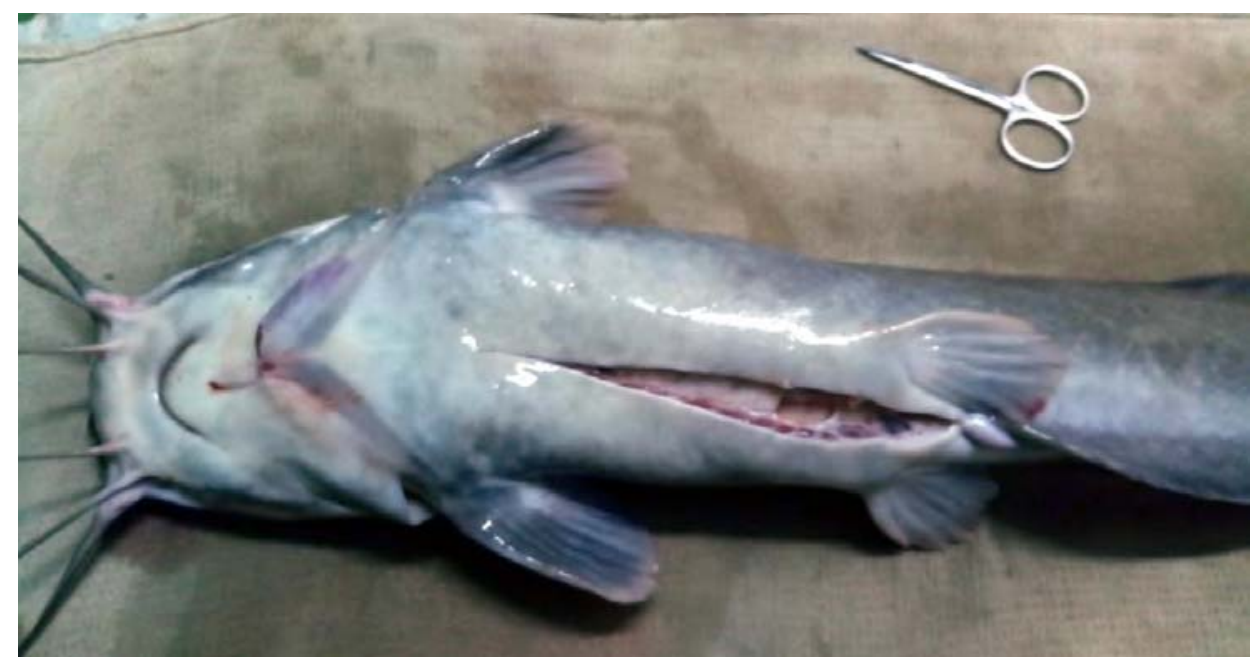

Fig. 1. Autopsy of a male African catfish to extract gonads.

\section{Physiological invasive method with the resection (ectomy)}

In order to keep catfish males alive, there is a surgical procedure for extracting genital products described in the article [3]. An incision is made in the abdominal wall and a part of the gonad of the fish is extracted. Then this material is used for the artificial insemination. The incision after these manipulations is sutured [17].

The invasive method is justified in selection works with the broodstock of the African catfish, because the killing of males does not allow to select males and form the broodstock. The same manipulations with the broodstock are carried out as with the method with the killing. But there is no need to kill the males during the sperm collection. The male must be immobilized when using the invasive method. The novocaine tight infiltration is suited for 
the local anesthesia. The general anesthesia is possible with clove oil, benzocaine, MS-222 or propiscin. After immobilization, it is necessary to make an incision in the abdominal wall carefully. Since the resection (ectomy) of the part of the gonad, the remaining part of the gonad must be held with surgical thread or treated with polymer medical glue, otherwise the seminal fluid will be poured into the abdominal cavity after the surgical suture is applied to the fish body. An incision is recommended to be treated with an antiseptic for the topical application (Figure 2). Although African catfish evolved under conditions that developed stamina and rapid regeneration of soft tissues in these fish [18], it does not guarantee $100 \%$ survival of males, because there is always a risk of infection of the wound and loss of internal organs. Also, the process of suturing is very painstaking and time-consuming.

The disadvantages of the method include the need to isolate the males who have undergone resection from the rest of the broodstock to complete healing of the sutures from a biopsy on the skin. If a fish with damaged skin is planted into a broodstock, the rest of the catfish respond to the invader aggressively and show cannibalism, killing a male with an unhealed seam to death.

The time required to carry out all these manipulations, both for suturing, and for skin regeneration and subsequent rematuration [17], increases several times as compared to simple killing. Therefore, the application of the invasive method for the industrial cultivation of African catfish is limited by experimental or selection purposes and for commercial production is inappropriate.

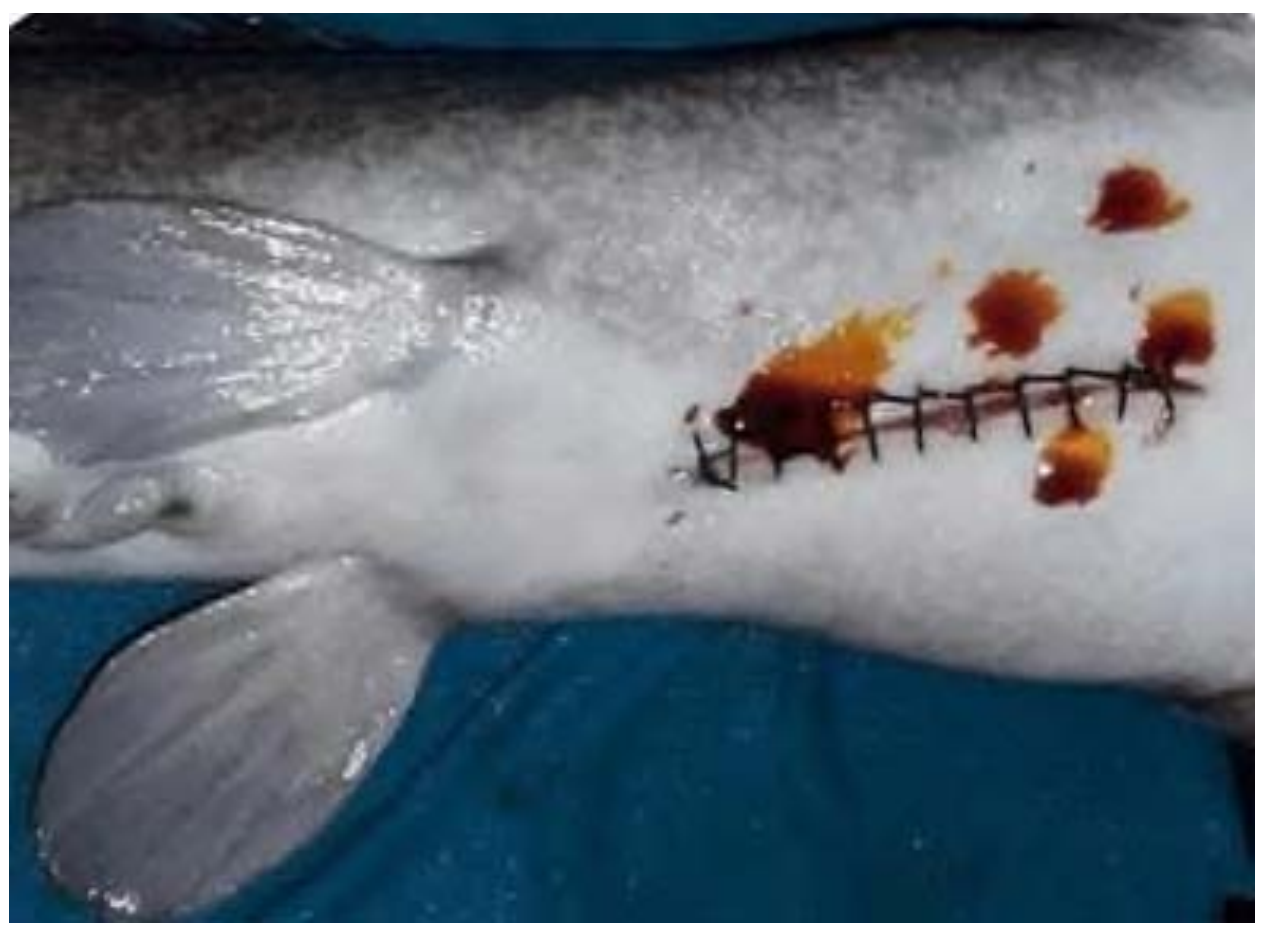

Fig. 2. Suture and bactericidal treatment with povidone-iodine after resection of part of the gonad. Source: http://fishconsult.org/? $p=14683$

\section{Physiological invasive method with gonad puncture}


We have proposed an alternative method of intravital obtaining of reproductive products from African catfish without the surgery by biopsy with a puncture through the abdominal wall. The basis for our study was the data from this article [19]. The invasive manipulation is possible without anesthesia. The method allows to reuse males for several reproduction cycles without a long labor-intensive process of rematuration. A main feature of this method is the high survival rate of males - usually at least $95 \%$. This method has the highest speed of manipulations of all known methods of spawning of the African catfish. Also, this procedure reduces the costs of fish farms because it takes fewer fish in broodstock to maintain both in the broodstock and in the pregrow-out one. In exceptional cases, if breeding work with males is not important, mature males can be selected from the grow-out stock with random sampling.

When spawning, fish are taken out of water and placed on the operating table. Anesthesia is usually not carried out if they weigh up to $2 \mathrm{~kg}$ (although this operation is sometimes used if it is carried out by one fish farmer). Larger fish should be immobilized with benzocaine, propiscin, MS-222 or clove oil. The sperm is extracted with a medical syringe (Figure 3). Then the seminal fluid is analyzed and a decision on its further use in breeding is made based on the results of the analyzes. The disadvantage of the method for taking reproductive products by puncture is the requirement of special skills and practice. Another difficulty is that some males sometimes have only one gonad. In such cases, the solution is using the ultrasound units to test the location and maturity of the gonads. It is also not recommended to do the punction with syringes and needles for insulin injections. Since they are short and thin, it complicates the collection of sperm and increases the risk of clogging of the needle channel with seminal fluid.

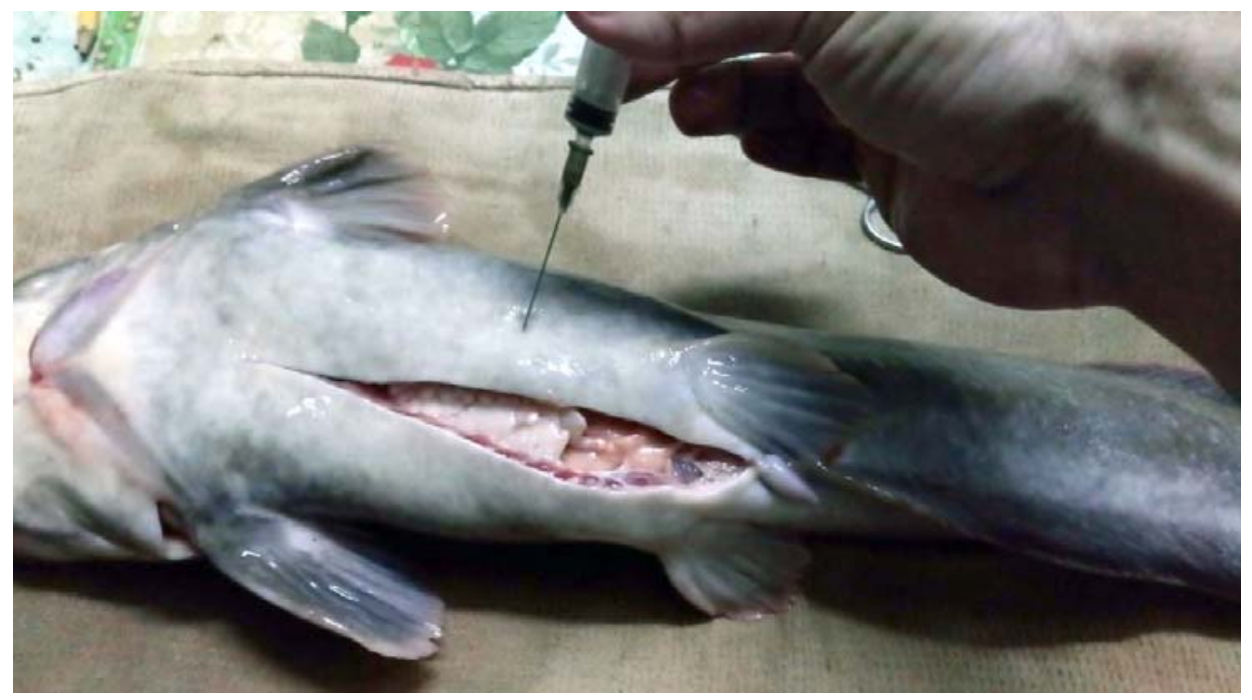

Fig. 3. Orientation and setting the needle at the right angle to the body of the fish to extract mature sperm

\section{Materials and methods}

The species of the hydrobiont is the African catfish (lat. Clarias gariepinus). Age - 1 year. Breeding to 100 grams was done in the RAS. The next period of growth took place in the biofloc tanks with heterotrophic activated sludge. The monthly food ration consisted of dry extruded feed for channel catfish manufactured by «Aquarex» with $36 \%$ of protein, $0.5 \%$ of fish biomass. The feed was given in equal portions 4 times a day. 
Males were taken from the tank with water temperature of $24^{\circ} \mathrm{C} \pm 0.5$. Ultrasound diagnostics of the maturity of males of African catfish was performed 4 days before spawning.

65 males and 25 females were stimulated with a preparation from carp pituitary treated with acetone. The average weight of the individual was $1250 \mathrm{~g}$. Mature genital products were obtained from the females in 8.5 hours. After receiving the eggs, sperm was collected from the males. The male was fixed on the special table (Figure 4).

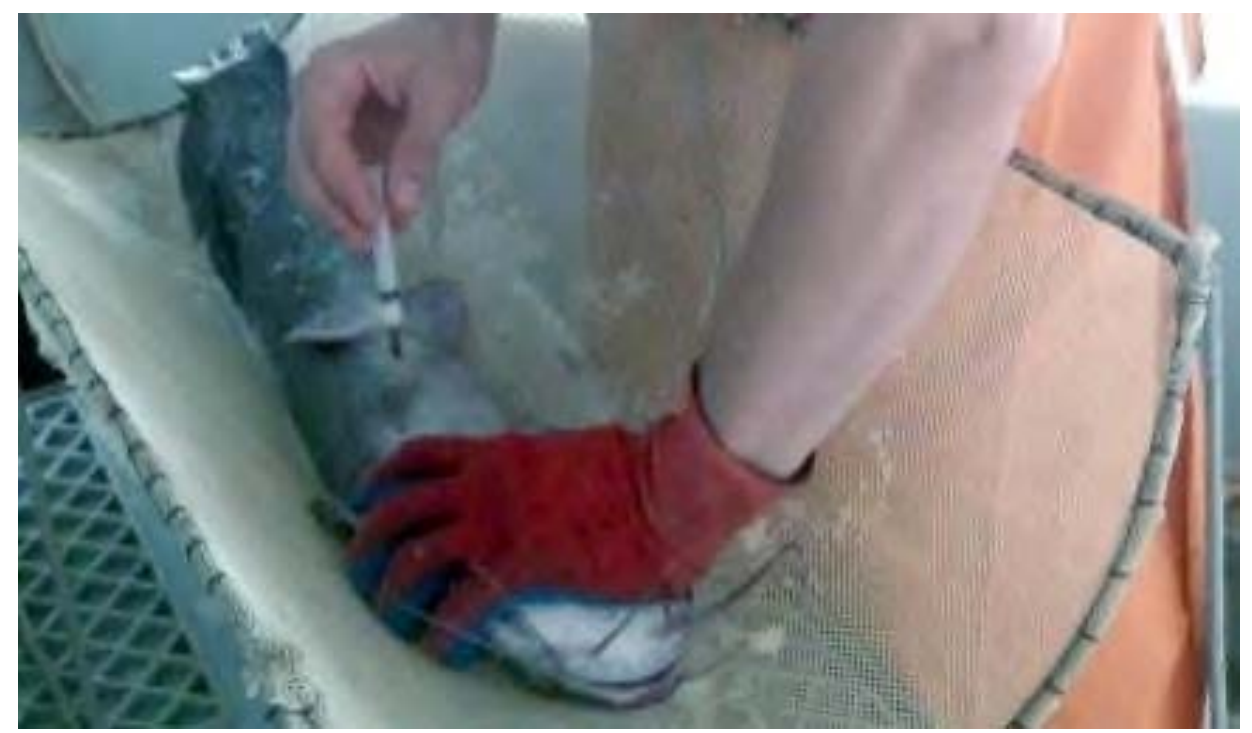

Fig. 4. Manipulations with a male catfish during sperm collection

The immobilized fish was wiped off mucus and other contaminants with boiled cotton towels. The location of the gonads was determined with an ultrasound apparatus (Figure 5). Semen was taken using a sterile syringe with a volume of no less than $2 \mathrm{ml}$.

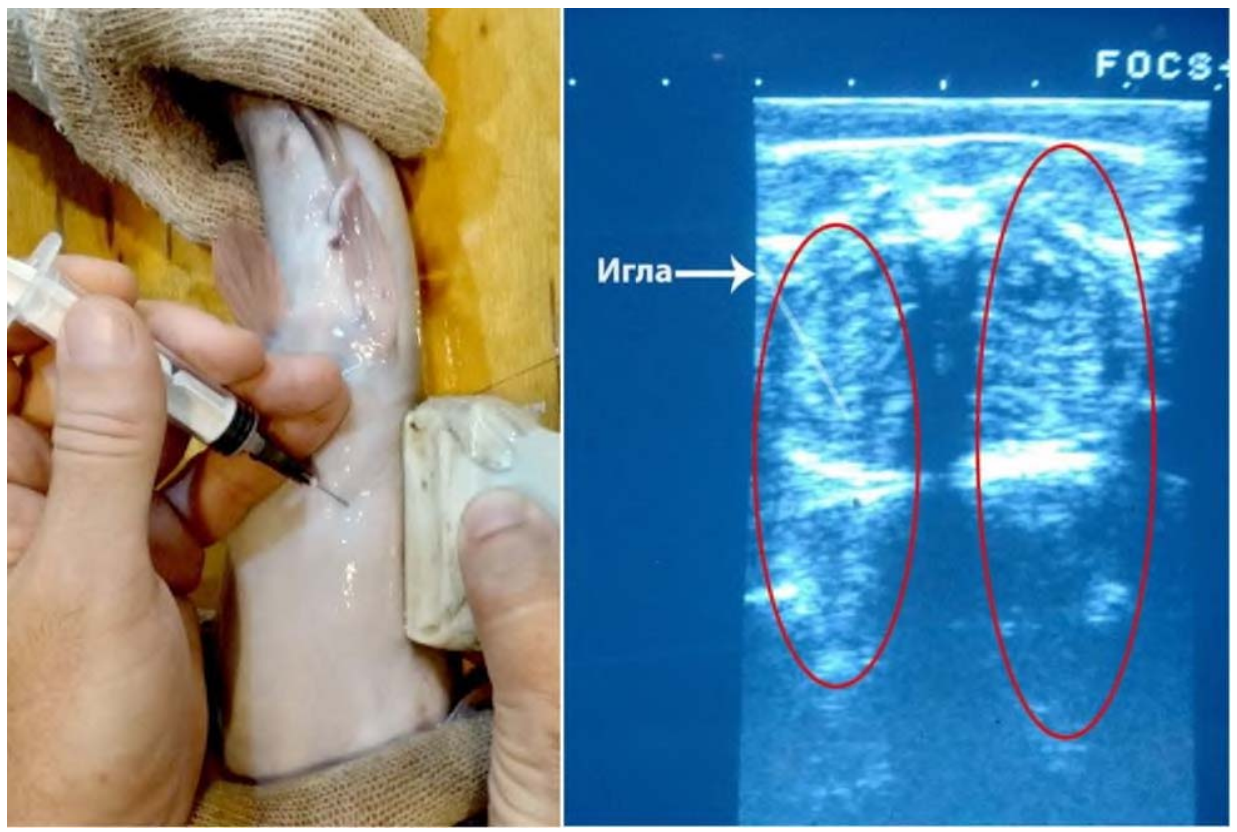


Fig. 5. Position and setting of the needle and ultrasound probe

The injection was carried out in several ways:

- at a 90 - degree angle to the surface of the body,

- at a 45 - degree cranial and caudal.

There were no difficulty to get to the gonads by any methods mentioned above. In this regard, we chose the first one and did the procedure at a 90 - degree angle.
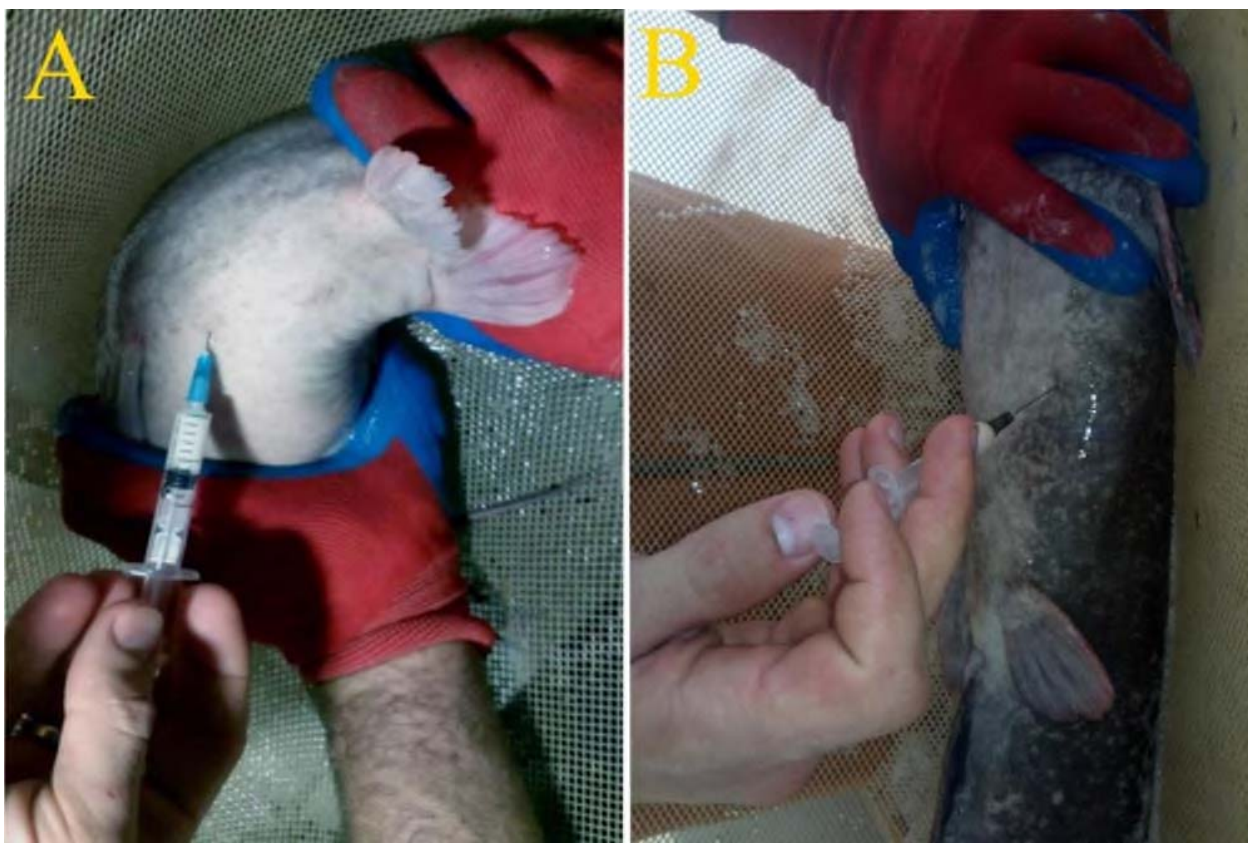

Fig. 6. Collecting of mature sperm with different positions of the male body

Table 1. Comparative characteristics of the methods for obtaining genital products of the African catfish

\begin{tabular}{|c|c|c|c|c|}
\hline \multicolumn{6}{|c|}{ Method of exploitation of males in a spawning company } \\
\hline $\begin{array}{c}\text { Category } \\
\text { Ecological } \\
\text { in the process }\end{array}$ & $\begin{array}{c}2-3 \text { for } 1 \\
\text { female }\end{array}$ & $\begin{array}{c}3 \text { for } 1 \\
\text { female }\end{array}$ & $\begin{array}{c}2-3 \text { for } 1 \\
\text { female }\end{array}$ & 2 for 1 female \\
\hline $\begin{array}{c}\text { Procedure duration } \\
\text { The complexity of } \\
\text { the procedure }\end{array}$ & A few days & $\begin{array}{c}1-3 \\
\text { minutes }\end{array}$ & $\begin{array}{c}10-30 \\
\text { minutes }\end{array}$ & $\begin{array}{c}\text { Less than } 1 \\
\text { minute }\end{array}$ \\
\hline $\begin{array}{c}\text { Control } \\
\text { procedure }\end{array}$ & $\begin{array}{c}\text { Uncontrolled } \\
\text { spawning }\end{array}$ & $\begin{array}{c}\text { Full } \\
\text { control }\end{array}$ & Full control & Full control \\
\hline $\begin{array}{c}\text { Reservoir for } \\
\text { spawning and } \\
\text { restoration of } \\
\text { males }\end{array}$ & $\begin{array}{c}\text { A } \\
\text { spawning } \\
\text { pond is } \\
\text { necessary }\end{array}$ & $\begin{array}{c}\text { A tank } \\
\text { for } \\
\text { spawning }\end{array}$ & $\begin{array}{c}\text { A tank } \\
\text { for } \\
\text { Recovery } \\
\text { separately } \\
\text { from } \\
\text { broodstock }\end{array}$ & $\begin{array}{c}\text { Males } \\
\text { are taken } \\
\text { fromediately } \\
\text { from the } \\
\text { tanks and } \\
\text { returned } \\
\text { there after } \\
\text { spawning }\end{array}$ \\
\hline Rematuration & Possible & Not & Partially & Possible \\
\hline
\end{tabular}




\begin{tabular}{|c|c|c|c|c|}
\hline of males & & possible & possible & \\
\hline Selection & Possible & $\begin{array}{c}\text { Not } \\
\text { possible }\end{array}$ & Possible & Possible \\
\hline
\end{tabular}

\section{Results and discussion}

The test punctures of the fish not stimulated by the pituitary showed that the males mature without any additional stimulation with hormonal preparations if they are kept under conditions of a biofloc system with suitable temperatures and feeding. Obtaining highquality reproductive products by puncture is possible from the fish with large, swollen urinary-genital papillae.

The risk of accumulation of visceral fat and degeneration of gonads increases if fish are being fed with poor-quality feed or improper feeding regime. In this case it is impossible to obtain genital products.

After the needle penetrates the gonads, it may be difficult to obtain seminal fluid. Due to the fact that the seminal fluid is not distributed throughout the gonads evenly and most mature sperm accumulates in the processes and serrated edge of gonads (Fig. 7), after inserting the needle, slightly massaging of the abdomen may be necessary. It is done $3-5 \mathrm{~cm}$ from the puncture and simplifies and speeds up the semen collection. Particles of tissue can also get into the hole of the needle, clogging it.

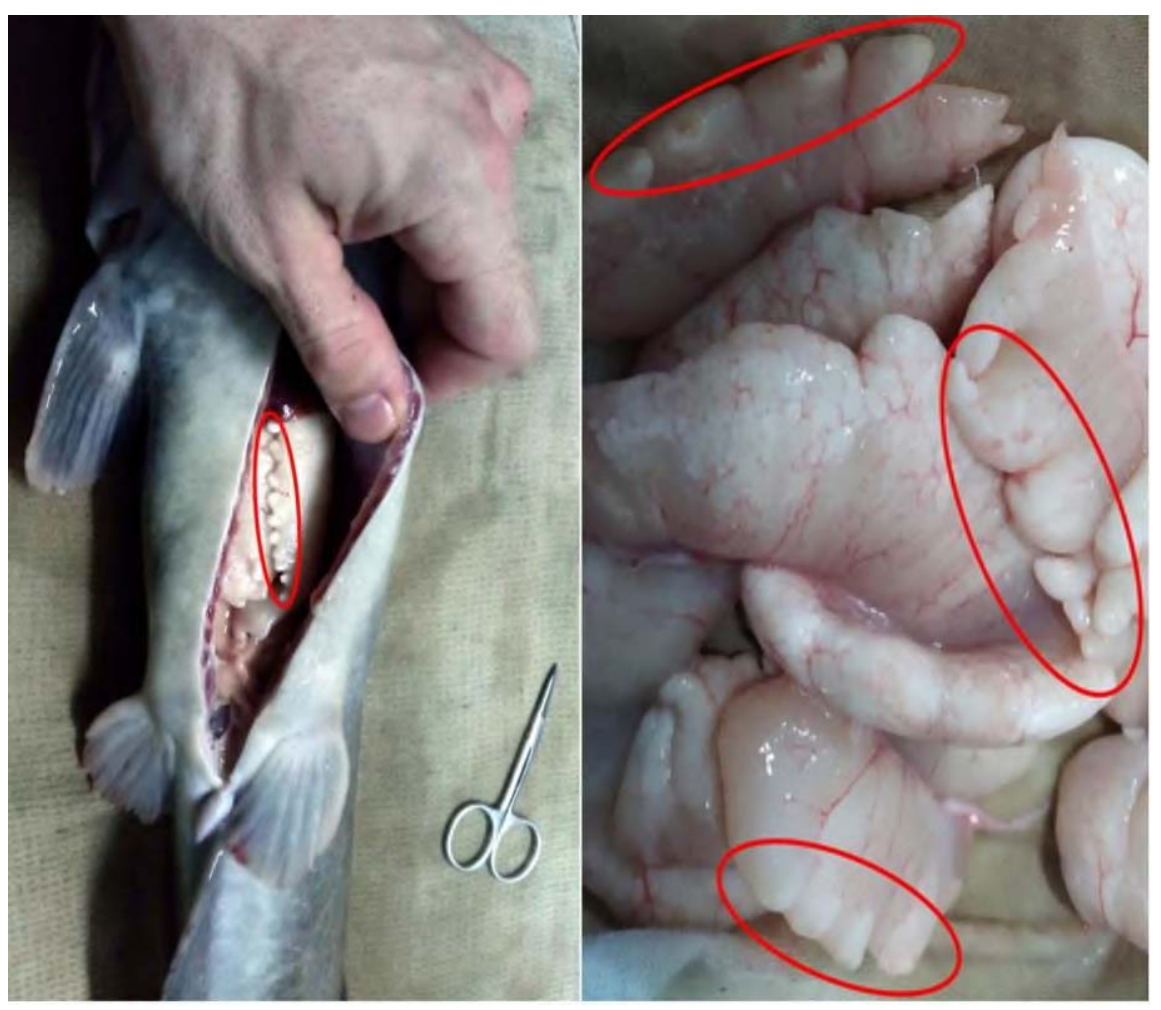

Fig. 7. Ovals indicate the processes and serrated edge of gonads with the maximum concentration of mature sperm. 
Mature seminal fluid in an average volume of $1.5 \pm 0.1 \mathrm{ml}$ from one male was taken from 43 out of 65 males using a disposable sterile syringe by the puncture method. We were unable to obtain the genital products from the other males. As ultrasonography has showed later, these males had a large amount of visceral fat and did not respond to the hormonal stimulation. A control autopsy revealed the absence of the left gonad in one of the males, the right one was not mature. The gonads of the other males also appeared underdeveloped or immature. After fertilization with the sperm, the eggs were laid for incubation in a MacDonald-type apparatus. Hatching occurred after 20 hours at a temperature of 27.2.

\section{Conclusion}

Even at the stage of the ultrasound testing, it is possible to determine the development of the gonads and the suitability of the male for further use as a pre-grow-out and grow-out broodstock. The definition of the seminal fluid quality, the number of sperms in it and their motility make possible to form a broodstock with higher reproductive potential and fertilization ability.

Summarizing our research, we would like to note the positive trends in the experience in obtaining genital products:

- the minimum amount of time spent on the procedure,

- higher survival rate after the manipulations,

- doing the breeding work and family formation,

- rematuration.

African catfish has a higher regenerative ability of gonads and it allows to use males of this species to carry out the spawning process several times.

\section{References}

1. C. C. Mylonasa, A. Fostierb, S. Zanuyc, Broodstock management and hormonal manipulations of fish reproduction, General and Comparative Endocrinology, 165(3), 516-534 (2010) doi: 10.1016/j.ygcen.2009.03.007

2. D. Kucharczyka, D. J. Kucharczykb, J. Nowosada, N. Omirzhanovac, Optimization of artificial insemination outcomes of African catfish (Clarias gariepinus) with differing hatchery conditions, Animal Reproduction Science, 211, 106222 (2019) doi:10.1016/j.anireprosci.2019.106222

3. S. K. Majhi, P. K. Maurya, S. Kumar, V. Mohindra, K. Kumar Lal, Non-invasive method for collection of Clarias magur (Hamilton, 1822) spermatozoa: A novel approach for catfish domestication, aquaculture and conservation, MethodsX, 519, 734737 (2020) doi: 10.1016/j.aquaculture.2019.734737

4. W. Srimai, S. Koonawootrittriron, P. Chaivichoo, W. Manee-aphai, A. Phu-onnim, U. Koolboon, U. Na-Nakorn, Selection response and genetic parameters for growth in North African catfish, Clarias gariepinus (Burchell, 1822), Aquaculture, 518, 734843 (2020) doi:10.1016/j.aquaculture.2019.734843

5. L. Nyina-Wamwiza, S. Milla, M-A. Pierrard, E. Rurangwa, S. N. M. Mandiki, K. J. W. Van Look, P. Kestemont, Partial and Total Fish Meal Replacement by Agricultural Products in the Diets Improve Sperm Quality in African Catfish (Clarias Gariepinus), Theriogenology, 77(1), 184-194 (2012) doi: 10.1016/j.theriogenology.2011.07.032

6. M. A. Essaa, H. A. Mabroukb, R. A. Mohameda, F. R. Michael, Evaluating different additive levels of yeast, Saccharomyces cerevisiae, on the growth and production 
performances of a hybrid of two populations of Egyptian African catfish, Clarias gariepinus, Aquaculture, $\quad 320(1-2), \quad 137-141 \quad$ (2011) doi: 10.1016/j.aquaculture.2011.08.015

7. T. Müllera, É. Ács, G. Beliczky, J. Makk, A. Földi, B. Kucska, L. Horváth, Á. Ittzés, Á. Hegyi, T. Szabó, B. Urbányi, N. N. Quyen, L. Orbán, M. Havasi, New observations about the fertilisation capacity and latency time of sperm inseminated into the ovary of African catfish (Clarias gariepinus), an oviparous modelfish, Aquaculture, 522, 735109 (2020) doi: 10.1016/j.aquaculture.2020.735109

8. S. Santi, V. Gennotte, A. Toguyeni, C. M. N. Antoine, C. Rougeot, Thermosensitivity of the sex differentiation process in the African catfish, Clarias gariepinus: Determination of the thermosensitive period, Aquaculture, 455, 73-80 (2016) doi: 10.1016/j.aquaculture.2016.01.009

9. S. Santi, V. Gennotte, M. Muller, C. Melard, A. Toguyeni, S. N. M. Mandiki, C. Rougeot, Sex-ratio, early sex steroid profiles and cyp19a1b, dmrt1 and foxl2 gene expressions upon high temperature treatment of undifferentiated African catfish juveniles (Clarias gariepinus), Aquaculture, 499, 140-148 (2019) doi: 10.1016/j.aquaculture.2018.09.033

10. J. Ekasaria, M. Agus, S. Wiyoto, W. Ratih, F. Hazanaha, G. S. Lenggaraa, R. Sulistiania, M. Alkahfia, M. Zairin Jr, Biofloc technology application in African catfish fingerling production: The effects on the reproductive performance of broodstock and the quality of eggs and larvae, Aquaculture, 464, 349-356 (2016) doi: 10.1016/j.aquaculture.2016.07.013

11. S. Asem-Hiablie, C. D. Church, H. A. Elliott, N. W. Shappell, H. L. Schoenfuss, P. Drechsel, C. F. Williams, A. L. Knopf, M. Y. Dabie, Serum Estrogenicity and Biological Responses in African Catfish Raised in Wastewater Ponds in Ghana, Science of The Total Environment, 463-464, 1182-1191 (2013) PMID: 23849063 DOI: $10.1016 /$ j.scitotenv.2013.06.032

12. E. M. Romanovaa, V. N. Lyubomirovaa, V. V. Romanov, M. E.Mukhitovaa,Tatyana M. Shlenkina, Seasonal studies of caviar production and the growth rate of the African catfish (Clarias gariepinus, Burchell, 1822), The Egyptian Journal of Aquatic Research, 44(4), 315-319 (2018) doi: 10.1016/j.ejar.2018.09.005

13. J. Beirão, T. B. Egeland, C. F. Purchase, J. T. Nordeide, Fish Sperm Competition in Hatcheries and Between Wild and Hatchery Origin Fish in Nature, Theriogenology, 133, 201-209 (2019) doi: 10.1016/j.theriogenology.2019.03.034

14. S. Sharaf, Effect of GnRHa, pimozide and Ovaprim on ovulation and plasma sex steroid hormones in African catfish Clarias gariepinus, Article (PDF Available) in Theriogenology, 77(8), 1709-1716 (2012) DOI: 10.1016/j.theriogenology.2011.12.019

15. B. B. Ajayia, J. O. Ogunsolab, O. I. Olatoyea, R. E. Antiac, S. Agbedea, Effects of pituitary extract, ovaprim, and bitter leaf (Vernonia amygdalina) on the histopathology of African catfish (Clarias gariepinus), Aquaculture and Fisheries, 3(6), 232-237(2018) doi: 10.1016/j.aaf.2018.10.001

16. W. N. El-Hawarrya, S. H. Abd El-Rahmanb, R. M. Shourbelaa, Breeding response and larval quality of African catfish (Clarias gariepinus, Burchell 1822) using different hormones/hormonal analogues with dopamine antagonist, The Egyptian Journal of Aquatic Research, 42(2), 231-239 (2016) doi: 10.1016/j.ejar.2016.06.003

17. O. T. Adebayo, E. A. Fasakin, J. A. Adewumi, Reproductive Performance of Partial Gonadectomized Male African Catfish, Clarias Gariepinus Broodstocks, 
Theriogenology, 77(6), 1050-1055 (2012) PMID: 22325211 DOI: 10.1016/j.theriogenology.2011.09.027

18. R. W.Schulz, W. Dijk, E. Chaves-Pozo, Á. García-López, L. R. de França, J. Bogerd, Sertoli cell proliferation in the adult testis is induced by unilateral gonadectomy in African catfish, General and Comparative Endocrinology, 177(1), 160-167(2012) doi: 10.1016/j.ygcen.2012.03.001

19. K. O. Idahor, Microscopic observation of spermatozoa in milt collected with syringe without sacrificing the male African Catfish (Clarias anguillaris B. 1911), International Journal of Fisheries and Aquatic Studies, 2(1), 88-91 (2014) 